\title{
Evaluation of Some Factors Associated with Potato Blackleg Disease
}

\author{
Christina B. Wegener ${ }^{1}$ \\ ${ }^{1}$ Julius Kühn-Institute (JKI), Federal Research Centre for Cultivated Plants, Institute for Resistance Research and \\ Stress Tolerance, Sanitz, Germany \\ Correspondence: Christina B. Wegener, Julius Kühn-Institute, Rudolf Schick-Platz 3, D-18190 Sanitz, Germany. \\ Tel: 49-382-094-5211. E-mail: christina.wegener@julius-kuehn.de
}

\author{
Received: October 31, 2019 Accepted: November 24, 2019 Online Published: January 2, 2020 \\ doi:10.5539/sar.v9n1p42 \\ URL: https://doi.org/10.5539/sar.v9n1p42
}

\begin{abstract}
Potato blackleg (blg) caused by Pectobacterium species leads to great economic losses in agriculture worldwide. In this study, three breeding clones with varying degree of disease tolerance, i.e. tolerant $(t)$, moderately tolerant (mt) and susceptible (s) to blg were evaluated in field trials for several disease related factors. The s-clone L 696 with its high portion of oversized tubers showed increased lenticel swellings and had a weak defense potential in its tuber tissue coinciding with low antioxidant capacities and reduced necrosis formation $48 \mathrm{~h}$ after incubation with Pectobacterium atrosepticum (Pba). The t-clone B 165, however, was outstanding in its tuber soft rot resistance and antioxidant levels and generated the best extent of necrosis after incubation with Pba among the genotypes. Moreover, B 165 expressed significantly higher $(\mathrm{P}<0.05)$ polyphenol oxidase $(\mathrm{PPO})$ and peroxidase (POD) activities in the external sprout basis (ESB) of its sprouting tubers, and histochemical analyses revealed embedding of lignin in ESB-tissue sections. Together with PPO, POD and phenols, this lignin forms a barrier that provided high protection of B 165-sprouts against Pba invasion and seems to be a key factor for blg tolerance. The mt-clone P 92388 with its medium-sized tubers had also a lower risk for infections. Hence, the oversized tubers and strong lenticel swellings can be seen as major risk factors for potato blg disease.
\end{abstract}

Keywords: Pectobacterium, soft rot, antioxidants, plant phenols, peroxidase, polyphenol oxidase, lignin

\section{Introduction}

Blackleg (blg) is one of the most important bacterial diseases of potatoes and leads to severe economic losses in agriculture globally, whereby climate change will strengthen this problem in the future (De Boer \& Rubio, 2016). Pectobacterium atrosepticum ( $\mathrm{Pba}$ ) is the major pathogen causing blg in Europe, Canada and USA (Perombelon, 2002; Toth et al., 2003). Also Dickeya species, e.g. D. dianthicola and D. solani (Czajkowski et al., 2011) as well as Pectobacterium carotovorum subsp. brasiliensis and P. wasabiae were found as pathogens (De Boer \& Rubio, 2016), in addition to P. carotovorum subsp. carotovorum (De Haan et al., 2008) and several other Pectobacterium species (Czajkowski et al., 2015). Dickeya infections are an emerging problem in Europe (Toth et al., 2011; Department of Agriculture, Environment and Rural Affairs [DAERA], 2019). The pathogenicity of the bacteria is based on a set of enzymes such as pectinases, cellulases, proteases and xylanases that are secreted all into the plant tissue and coordinately degrade the major cell wall polymers leading to soft rot and/or blackleg symptoms (Toth \& Birch, 2005). Major part of these enzyme mixtures are pectolytic enzymes, above all pectate lyases (PL), exo-polygalacturonate lyase, pectin lyase, pectin methyl esterase and polygalacturonase (Collmer \& Keen, 1986; Barras et al., 1994). PL isoenzymes that depolymerize pectate and pectin are predominant in this frame and act in a synergistic manner (Bartling et al., 1995).

Potato blg is a seed-borne disease (Fredericks \& Metcalf, 1970), whereby the pathogens invade the host tissue through wounds, bruises and lesions. The bacteria survive in lenticels and wounds during storage of the tubers (Perombelon, 1974; Toth et al., 2011). Most seed tubers are contaminated (Perombelon, 1974) and the rotted mother-tuber is often a main source for infection of stems and progeny tubers during plant growth (Perombelon, 1992). High moisture and anaerobic conditions facilitate the rotting of tubers during storage and field growth (Perombelon \& Lowe, 1975). Initiation of blg, however, depends on the concentration of bacteria, the soil water status and the temperature. Excess of water together with anaerobic conditions are helpful to overcome the plant defense potential (Perombelon, 2002). Pba prefers temperatures $<25^{\circ} \mathrm{C}$, while Dickeya species are adapted to higher values (Perombelon, 1992). The problem is that commercial cultivars are more or less susceptible to blg (Toth et al., 2011). Disease incidence ranging from 2-30\% and yield reductions of 20-25\% were reported (Tsror 
et al., 2009), whereby most economic losses are caused by downgrading and rejection of potatoes during seed tuber certifications (Toth et al., 2011). Treatment of the tubers with disinfectants, e.g. ethanol, hydrogen peroxide and organic acids such as salicylic acid can decrease the contamination rates (Czajkowski et al., 2013). But, this is an additional process that may interfere with human and animal health.

Improvement of blg tolerance by breeding efforts is another option. In this case, usable parameters associated with blg tolerance are needed for selection of promising genotypes. Hence, three potato clones with varying degree of disease tolerance, i.e. tolerant $(\mathrm{t})$, moderately tolerant $(\mathrm{mt})$ and susceptible $(\mathrm{s})$ to blg were chosen on the basis of long year experiences in breeding practice and evaluated for some disease-realated factors during a 2 -year field experiment. The potato plants were grown in field plots with four replications per genotype (GT). After harvest, the tubers of each genotype were analyzed for their soft rot resistance and antioxidant capacity measured as ascorbic acid (ACE) and trolox equivalent (TXE). Furthermore, the sprouting tubers were tested with regard to total amounts of soluble phenols (TSP), polyphenol oxidase (PPO) and peroxidase (POD) enzyme activities expressed in tuber tissue as well as in the internal (ISB) and external sprout basis (ESB). Embedding of lignin seen as a barrier against the spread of plant pathogens (Vance et al., 1980) was visualized by means of phloroglucinol-HCl staining in tissue sections excised from the ISB and ESB region of the test-tubers. Finally, some other factors that could be involved in the movement of Pba pathogens from contaminated tubers into the sprouts were assessed.

\section{Methods}

\subsection{Plant Material}

The breeding clones B 165 (tolerant; t), P 92388 (moderately tolerant; mt) and L 696 (susceptible; s) used in the experiments were from the EUROPLANT Plant Breeding Company, Lüneburg, Germany. The three genotypes were chosen on the basis of experiences in agricultural practice regarding their level in blg tolerance, which was validated by appropriate greenhouse tests with results published elsewhere (Wegener, 2013).

The field trials were conducted during two test years. The plants were grown in field plots with four replications per genotype at the JKI, Institute for Resistance Research and Stress Tolerance in Groß Lüsewitz, near Rostock. The seed tubers were hand planted in April with ten plants per genotype, $30 \mathrm{~cm}$ within-row spacing and $75 \mathrm{~cm}$ between rows. Fertilizer, herbicides and all other agronomic measures were applied according to local practice. After harvest at the end of September, the tuber yield and the number of tubers per plant as well as the number of oversized tubers (>90 $\mathrm{mm}$ in diameter) per 10 plants was determined. The tubers were then stored in controlled environment at $5{ }^{\circ} \mathrm{C}$ until the analyses started. Analyses of tuber soft rot resistance carried out in both years and necrosis formation (2. year) as well as the assay of antioxidants (1. year) started in November and were finished in December of each year. Total amounts of soluble phenols, PPO and POD activity expressed in tuber and sprout tissue of sprouting tubers were measured in March of the second year. Lignin specific staining on sprout tissue sections was performed at the same time point.

\subsection{Resistance Analyses}

\subsubsection{Cultivation of Pba Bacteria Used for Resistance Analyses}

The resistance of tuber tissue to $\mathrm{Pba}$ bacteria was determined as described recently (Wegener, 2002). For this purpose, Pectobacterium atrosepticum strain 43/15 (Culture collection: JKI, Institute for Resistance Research and Stress Tolerance) was cultivated in a shaken culture of $25 \mathrm{ml} \mathrm{LB}$-medium (pH 7.0) supplemented with $0.1 \%$ citrus pectin (Sigma-Aldrich, Taufkirchen, Germany) and $0.1 \%$ lyophilized potato cell sap for $24 \mathrm{~h}$ at $25^{\circ} \mathrm{C}$. After cultivation, the bacteria were centrifuged at $5000 \times \mathrm{g}$ for $5 \mathrm{~min}$ at $4{ }^{\circ} \mathrm{C}$ and then re-suspended in water for adjustment of the Pba-density $\left(\mathrm{A}_{600}\right)$ used for inoculation.

\subsubsection{Rotting and Necrosis Formation on Tuber Halves}

Six medium-sized tubers representing an average sample per GT and replication were cut into halves and seven sterile filter papers of $5 \mathrm{~mm}$ in diameter were placed on each tuber half, one in the pith and six around the outer region. Afterwards, $10 \mu \mathrm{l}$ of a Pba dilution adjusted at $5 \times 10^{8} \mathrm{cfu} \mathrm{ml}^{-1}$ were pipetted on each filter paper. After incubation in a wet chamber for $24 \mathrm{~h}$ and $48 \mathrm{~h}$ at $20^{\circ} \mathrm{C}$, the diameter of each rotting zone surrounding the infection focus was measured, and the extent of rotting was calculated per tuber half. In parallel, the extent of necrosis was determined $48 \mathrm{~h}$ after incubation with Pba and expressed per tuber half. The tests were carried out with two replications per experimental set. Standard deviation (SD) of this test was $\leq 5.0 \%$.

\subsubsection{Rotting in Sprouting Tubers}

Six tubers were taken as an average sample per GT and replication for each experimental set. For formation of 
sprouts of about $10 \mathrm{~mm}$ in length, the test-tubers were stored in a dark chamber at $20{ }^{\circ} \mathrm{C}$. Afterwards, two holes arranged opposite each other were drilled underneath the sprouts of each tuber using a $3 \mathrm{~mm}$ sterile metal stick. In a first set of trials, $50 \mu 1$ of a Pba dilution adjusted at $5 \times 10^{8} \mathrm{cfu} \mathrm{ml}^{-1}$ (a-test) were injected into each hole, while in a second set of trials (b-test), a higher Pba density $\left(10^{9} \mathrm{cfu} \mathrm{m}^{-1}\right)$ was used for inoculation. After one week of incubation at $20{ }^{\circ} \mathrm{C}$ in a wet chamber, the tubers of each experimental set were halved using a sterile knife and the progression of rotting as well as the necrosis formation was checked. The tests were carried out in the second year with two replications per experimental set.

\subsubsection{Transfer of Sprouts into the Soil}

After incubation with Pba under b-test conditions detailed above, individual sprouts were cut from rotted tubers of clone B 165 and transferred into pots (130 mm in diameter) filled with a sterile turf (95\%)-sand (5\%) mixture for plant growth and tuber production in the greenhouse from April to August. At the end of August, the tubers were harvested and stored for six month in a controlled environment at $5{ }^{\circ} \mathrm{C}$. All sprouts of the clones P 92388 and L 696 were totally rotted under b-test conditions and could not be used for growth in the glasshouse.

\section{Biochemical Analyses}

\subsection{Assay of Antioxidants}

Antioxidants (Aox) were measured in tuber tissue, whereby all extracts were prepared after wounding the tubers. Ten medium-sized tubers were taken as an average sample from each GT and replication. The tubers were halved using a sterile knife and stored for 24 hours at $20{ }^{\circ} \mathrm{C}$ with the wound-surface upwards in a wet chamber before two cylinders were cut from the outer region of each tuber half using a cork borer of $5 \mathrm{~mm}$ in diameter. For the assay of Aox following a method described by Wegener and Jansen (2010), $2 \mathrm{~mm}$ thick slices were excised by means of a scalpel from the upper side of each cylinder. The slices were pooled, and $3 \mathrm{~g}$ of slices were ground under liquid nitrogen using a mortar and pestle. The homogenate was suspended in $20 \mathrm{ml}$ of $85 \%(\mathrm{v} / \mathrm{v})$ ice cold ethanol (Roth, Karlsruhe, Germany). This suspension was stored on ice for $1 \mathrm{~h}$, occasionally shaken and then centrifuged for $10 \mathrm{~min}$ at $8000 \times \mathrm{g}$ and $4{ }^{\circ} \mathrm{C}$. The supernatant was diluted and used for the measurement of Aox on a Photochem instrument (AnalyticJena AG, Jena, Germany), utilizing an ACW kit for water soluble and an ACL kit for lipid soluble antioxidants according to the manufacturer's recommendations following a method described elsewhere (Popov \& Lewin, 1996). The amounts of Aox were calculated by means of an ascorbic acid (ascorbic acid equivalent; ACE) and a trolox calibration curve (trolox equivalent; TXE) using the Photochem software package. The results were expressed in microgram equivalents in antioxidant activity of each reference compound, i.e. as ACE and TXE per milligram of fresh weight. Measurements were carried out in triplicate with $\mathrm{SD} \leq 5 \%$.

\subsection{Assay of Soluble Phenols}

Total amounts of soluble phenols were determined in the tuber and sprout tissue of sprouting tubers. Ten medium sized tubers were taken as an average sample from each GT and replication, and stored in a dark chamber at $20^{\circ} \mathrm{C}$ until sprouts of about $10 \mathrm{~mm}$ in length were formed. The tissue extracts used for the TSP analyses (2. year) were prepared from the ESB and ISB tissue region as well as from the tuber tissue of sprouting test-tubers.

For preparation of ESB-extracts, all sprouts were removed from the tubers before a $5 \mathrm{~mm}$ thick tissue section was excised from each sprout basis and then cut into $1 \mathrm{~mm}$ thick slices using a scalpel. The slices were pooled, and $1 \mathrm{~g}$ of the slices was ground under liquid nitrogen using mortar and pestle. The homogenate was suspended in $4 \mathrm{ml}$ of methanol (Roth, Karlsruhe, Germany). This suspension was stirred slightly and after $1 \mathrm{~h}$ centrifuged at $6000 \times \mathrm{g}$ for $10 \mathrm{~min}$ at $4{ }^{\circ} \mathrm{C}$. The supernatant was removed, and the plant material re-extracted. Both extracts were combined before the total amounts of soluble phenols were assayed using Folin-Ciocalteu reagent (Sigma-Aldrich, Taufkirchen, Germany) according to Cahill and McComb (1992). The absorbance was measured at $725 \mathrm{~nm}$ on a UV spectrophotometer (Kontron Instruments, Neufahrn, Germany), whereby the standards were prepared from $p$-coumaric acid (Sigma-Aldrich). Total amounts of phenols (=coumaric acid equivalent) were expressed in grams per kilogram of fresh weight ( $\mathrm{fw}$ ). The analyses were performed in duplicate ( $\mathrm{SD} \leq 5 \%$ ).

For preparation of the ISB-extracts, a square of $5 \mathrm{~mm}$ side length was cut out from the tissue region underneath the sprouts of each test-tuber. All square sections were cut into $1 \mathrm{~mm}$ thick slices that were pooled, and $1 \mathrm{~g}$ of the slices was used for the preparation of extracts used for TSP analyses as detailed above. In order to prepare the tuber-extracts, the test-tubers were halved, and two cylinders of $5 \mathrm{~mm}$ in diameter were cut out from the outer region of each tuber half using a cork borer. Afterwards, a $2 \mathrm{~mm}$ thick slice was excised from the upper wound region of each cylinder using a scalpel. The slices were pooled, and $1 \mathrm{~g}$ of the slices was ground and then extracted. These extracts were used for the TSP analyses as described before. 


\subsection{Assay of PPO and POD Enzyme Activity}

PPO and POD activities were measured in tuber and sprout tissue. Ten medium-sized tubers were taken as an average sample from each GT and replication and stored for sprout formation as detailed above. The extracts used for the analyses were prepared from tuber tissue as well as from the ESB and ISB as described for the TSP analyses except, that $2 \mathrm{~g}$ of the slices were ground under liquid nitrogen using mortar and pestle. The homogenate was centrifuged at $13000 \times \mathrm{g}$ for $5 \mathrm{~min}$ at $4{ }^{\circ} \mathrm{C}$. The supernatant was diluted with sodium phosphate buffer adjusted to $\mathrm{pH} 6.0$ for the assay of PPO activity according to Jockusch (1966) with modifications (Wegener, 2002) and pH 6.5 for the analyses of POD following the method detailed by Bi et al. (1997) that was modified (Wegener et al., 2013). Measurements of PPO (546 nm) and POD $(470 \mathrm{~nm})$ were carried out at $20{ }^{\circ} \mathrm{C}$ on a UV spectrophotometer (Kontron Instruments, Neufahrn, Germany) using the kinetic program of this instrument. PPO and POD enzyme units were defined as increase in 0.1 absorbance units per minute and micro liter of the appropriate tissue extract. Measurements were carried out in triplicate $(\mathrm{SD} \leq 5 \%)$.

\subsection{Other Parameters}

The sprouting tubers of each genotype were studied for some other factors affecting potato blg. In this frame, the number of sprouts per 8 tubers was determined. Moreover, the wound-diameter was measured after the sprouts were removed from the tubers, and average values were calculated per ten tubers. Finally, phloroglucinol-HCl staining was used to visualize embedding of lignin in tissue sections excised from the sprout basis. These sprout tissue sections were covered with $50 \mu \mathrm{l}$ of $2 \%$ (w/v) phloroglucinol solution (Sigma-Aldrich) in ethanol (95\%) before a drop of $\mathrm{HCl}$ was added. After several seconds the tissue sections were rinsed with water and then analyzed by microscopy.

\subsection{Statistical Analyses}

The 2-year field experiments were carried out with four replications per GT. The data in the tables are presented as mean values \pm SD. Standard statistical methods were used for the analyses of the data. The differences in diameter of the rotted and/or necrotic area formed on the tuber halves after incubation with Pba between the GTs were computed by analyses of variance using the 2-way ANOVA procedure that was also utilized for evaluation of the differences in tuber yield, TSP, PPO and POD between the genotypes. In addition, these differences were valued by means of $t$-test for paired samples. $\mathrm{P} \leq 0.05$ was considered significant in all procedures. Correlation coefficients (Pearson) were calculated between individual parameters, whereby $\mathrm{P} \leq 0.05$ was regarded to be significant.

\section{Results}

\subsection{Blackleg Symptoms and Tuber Yield}

Also in the present field experiments a few plants showed characteristic blg symptoms. Potato blackleg disease starts with a stem rot (Figure 1a), while in a later stage, also the leaves can be attacked by pathogens and become dark (Figure 1b) before the plants are totally decayed. The photos were taken from a diseased plant of the s-clone L 696, grown in the first year. The other two GTs were less affected by blg disease, in both experimental years.

Clone L 696 produced the highest tuber yield among the GTs and differed significantly $(\mathrm{P}<0.05)$ in this respect from the t-clone B 165 (Table 1). Moreover, there were significant differences $(\mathrm{P}<0.05)$ between the GTs in the number of tubers per plant and in the number of oversized tubers per ten plants (Table 1). L 696 with its low number of tubers exhibited by far the highest portion of oversized tubers among the GTs. The differences in both parameters between L 696 and its counterparts were all statistically significant $(\mathrm{P}<0.05)$. Interestingly, clone B 165 and the mt-clone P 92388 had a significantly lower portion of large tubers than the s-clone L 696.

Table 1. Yield parameters, 1. Year

\begin{tabular}{llcc}
\hline Genotypes & Tuber yield (kg/plant) & Tubers/plant (n) & Tubers $>90 \mathrm{~mm}^{\dagger}$ per 10 plants (n) \\
\hline B 165 & $1.46 \pm 0.04 \mathrm{a}$ & $12.75 \pm 0.96 \mathrm{a}$ & $34.50 \pm 5.97 \mathrm{a}$ \\
P 92388 & $1.49 \pm 0.04 \mathrm{ab}$ & $18.25 \pm 1.70 \mathrm{~b}$ & $3.50 \pm 1.00 \mathrm{~b}$ \\
L 696 & $1.58 \pm 0.09 \mathrm{~b}$ & $8.75 \pm 0.96 \mathrm{c}$ & $48.00 \pm 7.30 \mathrm{c}$ \\
All GTs & $1.51 \pm 0.07$ & $13.25 \pm 4.04$ & $28.70 \pm 19.22$ \\
\hline
\end{tabular}

GT means followed by different letters within the same column differ significantly at $\mathrm{P}<0.05$. ${ }^{\text {tin }}$ diameter

\subsection{Resistance of Tuber Tissue to Pba}

For resistance analyses carried out in both years, the tuber halves were inoculated with Pba bacteria, and after a 
period of incubation, the extent of rotting was measured (Figure 2a), whereby in the second year, the extent of necrosis was determined in parallel (Figure 2b).

The results of the first year revealed that the extent of rotting was significantly reduced $(\mathrm{P}<0.05)$ on tuber halves of the t-clone B 165, compared to those of the other GTs (Table 2A). Thus, the other two clones exhibited notably higher rates of decay, i.e. $24 \mathrm{~h}$ (P 92388; $+61.0 \%$; $\mathrm{L} 696 ;+54.2 \%$ ) as well as $48 \mathrm{~h}$ after incubation with $\mathrm{Pba}(\mathrm{P} 92388 ;+163.2 \%$; L 696; $+74.7 \%$ ). Similar significant differences were found in the second year (Table 2B). Again, the other GTs displayed many times higher decay values than B 165 , especially $48 \mathrm{~h}$ after incubation with $\mathrm{Pba}(\mathrm{P} 93288 ; \times 5.4 ; \mathrm{L} 696 ; \times 5.5)$. It was also interesting that on B 165 -tubers the extent rotting decreased during the time-span between $24 \mathrm{~h}$ and $48 \mathrm{~h}$ of incubation with Pba, a tendency noticed in both years (Tables $2 \mathrm{~A}$, 2B). These values were reduced on average by $22.1 \%$ (1. year) and $69.8 \%$ (2. year), respectively. In contrast, the appropriate decay rates of the other GTs increased during this time-span, except L 696 in the first year (Table 2A). Furthermore, clone B 165 was outstanding in its necrosis formation measured $48 \mathrm{~h}$ after incubation with $\mathrm{Pba}$ (Table 2B). Thus, the extent of necrosis was on average many times higher on its tuber halves than on those of the clones P 92388 ( $\times 3.8)$ and L $696(\times 5.1)$. The differences in the extent of rotting ( $24 \mathrm{~h}$ and $48 \mathrm{~h}$; both years) as well as those in the extent of necrosis $(48 \mathrm{~h} ; 2$. year) between B 165 and its counterparts were all statistically significant $(\mathrm{P}<0.05)$. However, the clones P 92388 and L 696 did not differ significantly in all these parameters, in both experimental years (Tables 2A, 2B). There were also no significant differences in the extent of rotting between the two test years, i.e. within the GTs and on average.

Table 2A. Extent of rotting on tuber halves, 1. Year

\begin{tabular}{lll}
\hline Genotypes & Rotting $(\mathrm{mm})$ \\
\cline { 2 - 3 } & $24 \mathrm{~h}$ & $48 \mathrm{~h}$ \\
\hline B 165 & $37.10 \pm 11.23 \mathrm{a}$ & $28.90 \pm 7.71 \mathrm{a}$ \\
P 92388 & $59.74 \pm 7.47 \mathrm{~b}$ & $76.06 \pm 10.53 \mathrm{~b}^{*}$ \\
L 696 & $57.21 \pm 14.16 \mathrm{~b}$ & $50.48 \pm 14.37 \mathrm{~b}$ \\
All GTs & $51.35 \pm 14.08$ & $51.81 \pm 22.08$ \\
\hline
\end{tabular}

GT means followed by different letters within the same column differ significantly at $\mathrm{P}<0.05$. ${ }^{*}$ Difference between $24 \mathrm{~h}$ and $48 \mathrm{~h}$ of incubation with $\mathrm{Pba}$ is statistically significant at $\mathrm{P}<0.05$

Table 2B. Extent of rotting and extent of necrosis on tuber halves, 2. Year

\begin{tabular}{|c|c|c|c|}
\hline \multirow[t]{2}{*}{ Genotypes } & \multicolumn{2}{|l|}{ Rotting $(\mathrm{mm})$} & Necrosis (n \\
\hline & $24 \mathrm{~h}$ & $48 \mathrm{~h}$ & $48 \mathrm{~h}$ \\
\hline В 165 & $46.52 \pm$ & $14.04 \pm$ & 49.21 \\
\hline P 92388 & $70.69 \pm 5.25 b$ & $75.06 \pm 3.48 b$ & $12.85 \pm 5.15 b$ \\
\hline L 696 & $64.17 \pm 10.67 b$ & $77.40 \pm 6.37 b$ & $9.67 \pm 2.01 b$ \\
\hline All GTs & $60.46 \pm 12.14$ & $55.50 \pm 29.82$ & $23.91 \pm 18.18$ \\
\hline
\end{tabular}

GT means followed by different letters within the same column differ significantly at $\mathrm{P}<0.05$. There were no significant differences in the extent of rotting between $24 \mathrm{~h}$ and $48 \mathrm{~h}$ of incubation with Pba.

\subsection{Antioxidant Capacity of Tuber Tissue}

The antioxidant capacity, i.e. ACE and TXE values were measured $24 \mathrm{~h}$ after wounding the tubers. These results revealed that the t-clone B 165 generated the highest level in water and lipid soluble antioxidants among the GTs, and differed significantly $(\mathrm{P}<0.05)$ in this respect from clone L 696 (Table 2C). However, between the clones B 165 and P 92388 the differences in both types of antioxidants were all statistically not significant. Moreover, it was interesting that the ACE and TXE data (Table 2C) could be correlated with the extent of rotting (Table 2A), assayed $24 \mathrm{~h}$ and $48 \mathrm{~h}$ after incubation with Pba. But, all these correlations were statistically not significant.

\subsection{Resistance Analysis of Sprouting Tubers}

In the second year, also sprouting tubers were analyzed for their resistance properties. In a first set of trials $2 \times$ $50 \mu \mathrm{l}$ of a Pba dilution adjusted at $5 \times 10^{8} \mathrm{cfu} \mathrm{ml}^{-1}$ (a-test) were pipetted underneath the sprouts of each test-tuber. After one week of incubation, all infected tubers were cut longitudinally and then checked for soft rot symptoms. 
Table 2C. Antioxidant capacity in tuber tissue and correlations, 1. Year

\begin{tabular}{lll}
\hline Genotypes & ACE & TXE $\left(\mu \mathrm{g} \mathrm{mg}^{-1}\right)$ \\
\hline B 165 & $0.32 \pm 0.05 \mathrm{a}$ & $0.23 \pm 0.02 \mathrm{a}$ \\
P 92388 & $0.28 \pm 0.04 \mathrm{a}$ & $0.19 \pm 0.02 \mathrm{ab}$ \\
L 696 & $0.17 \pm 0.03 \mathrm{~b}$ & $0.18 \pm 0.02 \mathrm{~b}$ \\
All GTs (3) & $0.26 \pm 0.07$ & $0.20 \pm 0.03$ \\
Extent of rotting (Table 2A) & Correlations $^{(\mathrm{r})}$ & Correlations $^{(\mathrm{r})}$ \\
24 h, $\mathrm{n}=12$ & -0.34 & -0.34 \\
48 $\mathrm{h}, \mathrm{n}=12$ & -0.21 & -0.31 \\
\hline
\end{tabular}

Correlation coefficients ${ }^{(\mathrm{r})}$ across GTs between the extent of rotting and the ACE/TXE data were all statistically not significant

Under these conditions, however, no progressive soft rot could be initiated. On the contrary, all tubers inoculated with Pba showed strong necrosis formation. This could be observed with all GTs (Figure 3) involved in the test series, whereby white layers of corky cells were most pronounced in tubers from the clones P 92388 and L 696. Hence, in a next set of trials the Pba-density used for infection was enhanced (b-test; $10^{9} \mathrm{cfu} \mathrm{ml}^{-1}$ ). As a result, the tubers and sprouts of the clones P 92388 and L 696 were totally rotted after one week of incubation, and also the tubers of the t-clone B 165 showed typical soft rot symptoms (Figure 4a). However, the sprouts of this clone remained more or less unaffected by pathogens. Individual sprouts excised from the rotted B 165-tubers could be transferred into the soil (Figure $4 \mathrm{~b}$ ) for plant growth in pots (Figure 4c) and production of healthy progeny tubers in the greenhouse (Figure 4d). Interestingly, B 165-derived sprouts were found to be a bit hard and woody, and in tissue sections cut from their sprout basis more or less thick fibers became visible. This could be observed after $24 \mathrm{~h}$ (Figure 5a) and became more clear $48 \mathrm{~h}$ after incubation of the tissue slices (Figure 5b). Phloroglucinol-HCl staining indeed revealed an embedding of lignin in the sprout tissue (Figure 5c), a property less noticed within appropriate tissue samples derived from the s-clone L 696 (Figure 5d). Its sprouts and also those of the mt-clone P 92388 were more thick and fleshy and less fibrous and/or woody.

\subsection{Biochemical Analysis of Sprouting Tubers}

\subsubsection{Total Soluble Phenols}

The total amounts of soluble phenols were, on average, many times higher in the ISB $(\times 6.6)$ and above all in the ESB $(\times 12.6)$ than in the tuber tissue tissue of sprouting tubers (Table 3A). This tendency was found with all GTs involved in the studies. The differences in TSP between these three tissue types were all statistically significant $(\mathrm{P}<0.05)$, i.e. on average and within the GTs. Interestingly, the t-clone B 165 exhibited the highest level of TSP in tuber tissue of its sprouting tubers among the GTs, followed by the clones P 92388 and L 696 (Table 3A). The differences in TSP contents of tuber tissue between the genotypes were all statistically significant $(\mathrm{P}<0.05)$. Regarding ISB-samples, L 696 exhibited the highest level in TSP among the GTs and differed significantly (P< 0.05 ) in this respect from the other clones (Table 3A) that were not too different in their ISB-TSP data. Moreover, the results revealed that the clones L 696 and B 165 had similar high TSP contents in their ESB extracts (Table $3 \mathrm{~A})$, while the mt-clone $\mathrm{P} 92388$ ranked on the lowest level in this respect and differed significantly $(\mathrm{P}<0.05)$ from the first two genotypes.

Table 3A. Total amounts of soluble phenols in tuber tissue as well as in the ISB and ESB, 2. Year

\begin{tabular}{llll}
\hline Genotypes & \multicolumn{3}{l}{ Soluble phenols $\left(\mathrm{mg} \mathrm{g}^{-1}\right)$} \\
\cline { 2 - 4 } & Tuber tissue & ISB & \multicolumn{1}{l}{ ESB } \\
\hline B 165 & $0.97 \pm 0.05 \mathrm{a}$ & $4.57 \pm 0.22 \mathrm{a}$ & $11.04 \pm 1.77 \mathrm{a}$ \\
P 92388 & $0.71 \pm 0.06 \mathrm{~b}$ & $3.99 \pm 0.53 \mathrm{a}$ & $4.71 \pm 0.08 \mathrm{~b}$ \\
L 696 & $0.57 \pm 0.07 \mathrm{c}$ & $6.38 \pm 0.55 \mathrm{~b}$ & $12.49 \pm 0.81 \mathrm{a}$ \\
All GTs & $0.75 \pm 0.18$ & $4.98 \pm 1.12$ & $9.41 \pm 3.56$ \\
\hline
\end{tabular}

GT means followed by different letters within the same column differ significantly at $\mathrm{P}<0.05$. The differences between the groups were all statistically significant at $\mathrm{P}<0.05$, within the GTs and on average.

\subsubsection{PPO Activity}

Compared to tuber tissue, the PPO activity was, on average, many times higher in the ISB $(\times 23.2)$ and above all in the ESB ( $\times 61.4)$ of sprouting tubers (Table 3B). The differences in PPO between the three sample types were 
all statistically significant $(\mathrm{P}<0.05)$, i.e. on average and within the GTs. It was important that by far the highest PPO levels were found in the ESB of all three genotypes. The s-clone L 696 had the lowest PPO activity in tuber tissue of its sprouting tubers among the GTs and differed significantly $(\mathrm{P}<0.05)$ in this respect from the other two GTs that had similar PPO values (Figure 3B). Regarding ISB-extracts, there were no significant differences in PPO between the GTs. Within the ESB-samples, B 165 displayed the highest PPO activity (Figure 3B) and differed significantly $(\mathrm{P}<0.05)$ in this respect from the other genotypes that were similar in their ESB-PPO data.

\subsubsection{POD Activity}

The POD activity was on average many times higher in the ISB $(\times 14.9)$ and ESB $(\times 28.2)$ region than in the tuber tissue of sprouting tubers (Table 3C). The differences in POD between the three tissue types were all statistically significant $(\mathrm{P}<0.05)$, on average and within the GTs. It was interesting, that again the ESB exhibited the highest level in POD activity among the different tissue-types.

Table 3B. PPO activity in tuber tissue as well as in the ISB and ESB, 2. Year

\begin{tabular}{llll}
\hline Genotypes & \multicolumn{3}{l}{ PPO activity $\left(\mathrm{U} \mathrm{\mu l}^{-1} \mathrm{~min}^{-1}\right)$} \\
\cline { 2 - 4 } & Tuber tissue & ISB & ESB \\
\hline B 165 & $0.14 \pm 0.02 \mathrm{a}$ & $2.48 \pm 0.23 \mathrm{a}$ & $9.89 \pm 0.69 \mathrm{a}$ \\
P 92388 & $0.15 \pm 0.02 \mathrm{a}$ & $3.31 \pm 0.45 \mathrm{a}$ & $5.94 \pm 0.53 \mathrm{~b}$ \\
L 696 & $0.08 \pm 0.02 \mathrm{~b}$ & $2.57 \pm 0.38 \mathrm{a}$ & $6.28 \pm 0.27 \mathrm{~b}$ \\
All GTs & $0.12 \pm 0.03$ & $2.78 \pm 0.52$ & $7.37 \pm 1.87$ \\
\hline
\end{tabular}

GT means followed by different letters within the same column differ significantly at $\mathrm{P}<0.05$. The differences between the groups were all statistically significant at $\mathrm{P}<0.05$, within the GTs and on average.

The three clones differed significantly in their POD activity expressed in the tuber tissue of sprouting tubers (Table 3C), whereby L 696 ranked on the highest level in this respect. The latter also exhibited the highest POD activity in its ISB and differed significantly $(\mathrm{P}<0.05)$ in this respect from the other GTs which were similar in their ISB-POD data (Table 3C). Regarding the ESB-extracts, the t-clone B 165 ranked on the highest level in its POD activity among the GTs (Figure $3 \mathrm{C})$, and differed significantly $(\mathrm{P}<0.05)$ from its counterparts that were not too different in their ESB-POD data.

Table 3C. POD activity in tuber tissue as well as in the ISB and ESB, 2. Year

\begin{tabular}{llll}
\hline Genotypes & \multicolumn{3}{l}{ POD activity $\left({\left.\mathrm{U} \mu 1^{-1} \min ^{-1}\right)}\right.$} \\
\cline { 2 - 4 } & Tuber tissue & ISB & ESB \\
\hline B 165 & $0.46 \pm 0.03 \mathrm{a}$ & $6.16 \pm 0.27 \mathrm{a}$ & $13.52 \pm 1.48 \mathrm{a}$ \\
P 92388 & $0.31 \pm 0.01 \mathrm{~b}$ & $6.07 \pm 0.32 \mathrm{a}$ & $12.14 \pm 0.17 \mathrm{~b}$ \\
L 696 & $0.56 \pm 0.02 \mathrm{c}$ & $7.42 \pm 0.25 \mathrm{~b}$ & $11.56 \pm 0.69 \mathrm{~b}$ \\
All GTs & $0.44 \pm 0.11$ & $6.55 \pm 0.68$ & $12.41 \pm 1.25$ \\
\hline
\end{tabular}

GT means followed by different letters within the same column differ significantly at $\mathrm{P}<0.05$. The differences between the groups were all statistically significant at $\mathrm{P}<0.05$, within the GTs and on average.

\subsubsection{Other Factors}

The studies revealed that the t-clone B 165 had on average the highest number of sprouts among the GTs and differed significantly $(\mathrm{P}<0.05)$ in this respect from the s-clone L 696 (Table 4) which ranked on the lowest level. But, clone B 165 and the mt-clone P 92388 did not differ significantly in their total number of sprouts.

Table 4. Number of sprouts and wound-diameter measured after removal of sprouts from the tubers, 2. Year

\begin{tabular}{lll}
\hline Genotypes & Sprouts/8 tubers $(\mathrm{n})$ & Wound-diameter $(\mathrm{mm})(10$ tubers $)$ \\
\hline B 165 & $25.50 \pm 4.66 \mathrm{a}$ & $1.82 \pm 0.29 \mathrm{a}$ \\
P 92388 & $23.75 \pm 0.96 \mathrm{a}$ & $3.12 \pm 0.38 \mathrm{~b}$ \\
L 696 & $21.00 \pm 1.15 \mathrm{~b}$ & $3.34 \pm 0.36 \mathrm{~b}$ \\
All GTs & $23.42 \pm 3.02$ & $2.76 \pm 0.73$ \\
\hline
\end{tabular}

GT means followed by different letters within the same column differ significantly at $\mathrm{P}<0.05$.

Moreover, it was found that the two clones P $92388(\times 1.7)$ and L $696(\times 1.8)$ showed a greater wound-diameter measured after the sprouts were removed from their test-tubers than the t-clone B 165 (Table 4). The differences 
in wound-diameter between B 165 and its counterparts were all statistically significant $(\mathrm{P}<0.05)$. However, the first two GTs had a similar high wound-diameter and did not differ significantly in this respect.

\section{Discussion}

Potato blackleg disease is becoming increasingly important in agricultural practice. Breeding for blg tolerance as a highly complex trait could be a strategy to solve this problem in the future. Hence, it was the aim of this work to identify factors facilitating blg and to find specific parameters mediating tolerance to this disease.

\subsection{Characteristics of the s-clone L 696}

As expected, the s-clone L 696 failed totally due to blg in pre-tests carried out under conditions of water logging in the greenhouse (Wegener, 2013). Also in the present field trials a few plants of this GT showed blg symptoms (Figure 1), while the other two clones were less affected by pathogens. Nevertheless, L 696 produced the highest tuber yield among the GTs and had the highest portion of oversized tubers (Table 1). However, this high number of large tubers may be a risk factor with regard to blg. Thus, potatoes are increasingly damaged due to extensive mechanization in agriculture, i.e. the tubers are brushed, washed, pre-packed and transported over long distances (Poberezny et al., 2017). Under these conditions, the oversized tubers might be more often damaged than small ones, whereby wounds serve as an entry for pathogens. The mt-clone P 92388 with its more medium-sized tubers (Table 1) seems to be in a better position in this respect than the s-clone L 696.

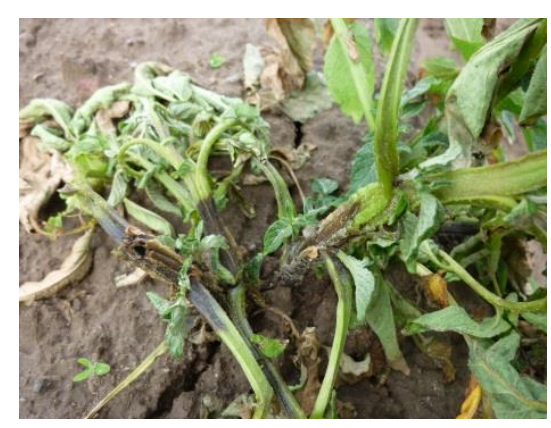

(a)

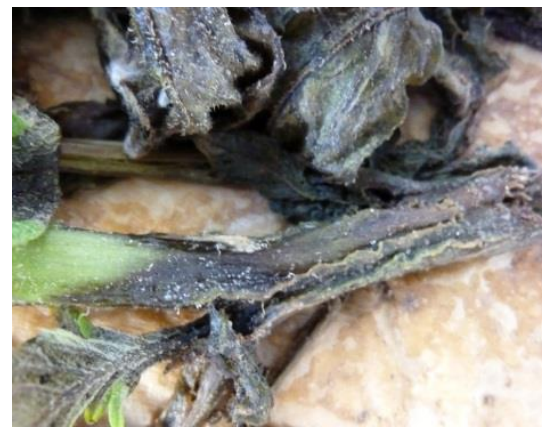

(b)

Figure 1. Blackleg disease on a field grown plant of the s-clone L 696 (a) as well as in stems and leaves (b)

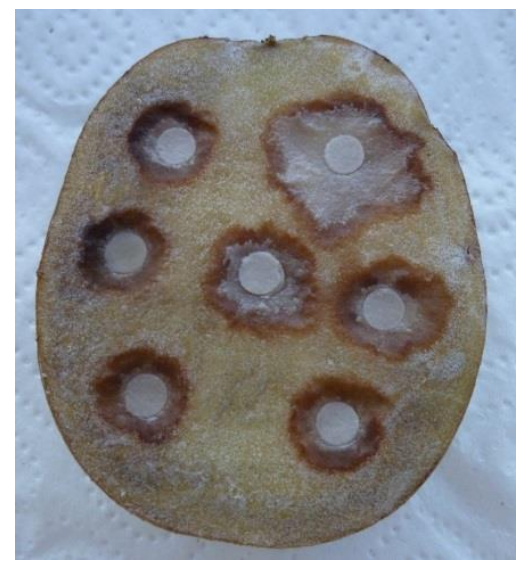

(a)

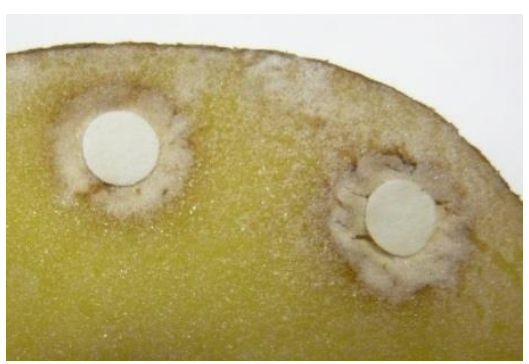

(b)

Figure 2. Rotting on a tuber half incubated at $20{ }^{\circ} \mathrm{C}$ in a wet chamber with Pba bacteria at $5 \times 10^{8} \mathrm{cfu} \mathrm{ml}^{-1}$ for 48 hours (a) and necrosis formation under same conditions (b)

Furthermore, L 696 showed increased lenticel swellings under wet conditions (Wegener, 2013). These swellings often lead to breaks as points of entry for pathogens which survive in lenticels and wounds throughout storage of the tubers (Perombelon, 1974). This problem, again, may be strengthened by the fact that the L 696-tuber tissue was rather susceptible to soft rot, a disease directly related to blg. In both years, the extent of rotting was notably enhanced on tubers of the s-clone L 696, compared to those of the t-clone B 165 (Table 2A, 2B). This could be 
observed $24 \mathrm{~h}$ and $48 \mathrm{~h}$ after incubation with Pba. On the other hand, L 696 showed the lowest extent of necrosis on its tuber halves among the GTs (Table 2B). Necrosis formation, again, indicates a successful plant defense and was many times higher on the B 165-tubers ( $\times 5.1)$. All this implies, that L 696 had a relatively weak defense potential in its tuber tissue, i.e. once pathogens have entered its tubers through wounds or breaks, they proliferate rapidly (Table 2A, 2B), since there is no strong capacity to resist an invasion. But, high densities of pathogens in tuber tissue play a major role for initiation of blg (Perombelon, 2002). It was not surprising thus that L696 was found to be susceptible to blg. A high portion of oversized tubers, strong lenticel swellings and a weak defense potential are all factors facilitating blg disease in this case.

In addition, L 696 generated the lowest antioxidant potential among the GTs (Table 2C), whereby the ACE and TXE values were measured $24 \mathrm{~h}$ after wounding the tubers. Wounding, again, elicits an increase in antioxidants, a process coinciding with accumulation of phenolic compounds in plant tissue (Reyes \& Cisneros-Zevallos, 2003; Reyes et al., 2007). Plant phenolics, e.g. chlorogenic, caffeic, cinnamic and ferulic acid as well as phytoalexins like rishitin and phytuberin play an essential role in the soft rot resistance of potatoes, because they all generate antibacterial activities (Ghanekar et al., 1984; Kumar et al., 1991). Especially, this last aspect may explain why L 696 was less resistant to tuber soft rot than the t-clone B 165 (Table 2A, 2B) that had much higher rates of Aox including these phenols in its tuber tissue (Table 2C). Moreover, low molecular weight phenols are involved in the synthesis of suberin, lignin and lignin-like polymers that all contribute to wound healing and act as protective barriers against pathogens. In fact, lignin/suberin layers cannot be degraded by patho-enzymes that are secreted by microorganisms into the plant tissue (Vance et al., 1980). Together with phenols, they are part of an active plant defense (Nicholson \& Hammerschmidt, 1992). For example, imbedding of lignin and suberin in the cell walls inhibited a spread of Pba bacteria in potato tuber tissue (Fox et al., 1971; Fox et al., 1972). Also in this respect, the s-clone L 696 was in a less comfortable position than the other GTs, mainly due to its weak necrosis formation (Table 2B), a process that is based on lignin and suberin deposition in the cell walls of necrotic lesions (Rittinger et al., 1987). This means that a low level in Aox (Table 2C) and this reduced necrosis formation (Table 2B) were additional factors that contributed to the susceptibility of clone L 696 to tuber soft rot (Tables 2A, 2B), a disease seen as a main source of infection for potato blg (Perombelon, 1992).

Interestingly, L 696 differed significantly $(\mathrm{P}<0.05)$ in all parameters, i.e. extent of rotting (Table 2A, 2B), extent of necrosis (Table 2B) and antioxidant capacity (Table 2C) from the t-clone B 165 . However, between the clones L 696 and P 92388 all these differences were less convincing, although, both GTs differed in their degree of blg tolerance. Clone P 92388 was moderately tolerant, while L 696 was susceptible to blg. This differentiation could only be based on the facts that L 696 had a higher portion of large tubers (Table 1) and showed stronger lenticel swellings than P 92388 (Wegener, 2013). Both are factors supporting pathogen invasion and when this coincides with susceptible tuber tissue as observed in the case of the s-clone L 696, the invading pathogens have optimal pre-conditions to propagate, and later, they can move from contaminated tubers into the sprouts and initiate blg. Obviously, P 92388 with its more medium sized tubers (Table 1) had a smaller risk for infections and was thus moderately tolerant to blg in agricultural practice. All this underlines the negative role of oversized tubers and strong lenticel swellings in blg disease control.

\subsection{Characteristics of the t-clone B 165}

The t-clone B 165 with its reduced tuber yield had a significantly lower portion of large tubers $(\mathrm{P}<0.05)$ than clone L 696 (Table 1), and also its lenticel swelling was less pronounced (Wegener, 2013). Moreover, B 165 was outstanding in its resistance to tuber soft rot. In both years, the extent of rotting measured $24 \mathrm{~h}$ and $48 \mathrm{~h}$ after incubation with Pba was significantly reduced on its tubers, compared to those of the other GTs (Table 2A, 2B). In addition, B 165 generated the highest antioxidant capacity among the GTs (Table 2C), a fact coinciding with the best extent of necrosis measured $48 \mathrm{~h}$ after incubation with Pba (Table 2B).

With it, the t-clone B 165 combined a high level of Aox (Table 2C) with efficient necrosis formation (Table 2B) and a good soft rot resistance (Table 2A, 2B), and had thus optimal pre-conditions for a successful defense of invading pathogens. But, all these positive traits seem to be generated on the costs of its tuber yield which was reduced, compared to the other GTs (Table 1). Doubtless, the blg tolerance of this breeding clone has its price.

\subsection{Characteristics of Sprouting Tubers}

The pathogens normally move from contaminated tubers into the sprouts or stems, where they cause blg. It was interesting thus to study sprouting tubers for total soluble phenols (TSP) and with regard to resistance mediating enzymes like PPO and POD expressed in tuber tissue as well as in the ISB and ESB.

The results revealed that the t-clone B 165 had the highest TSP contents in the tuber tissue of its sprouting tubers among the genotypes (Table 3A), whereby the differences in this respect between B 165 and the other GTs were 
all statistically significant. Obviously, such high amounts of phenols contribute to the blg tolerance of this clone. In addition, the specific role of phenols is supported by the fact that their total amounts increased dramatically, starting from the tuber tissue of sprouting tubers via the ISB (located inside the tubers) to the ESB (outside the tubers), a tendency noticed within all GTs involved in the tests (Table 3A). In comparison to tuber tissue, the amounts of phenols were on average 6.6-times higher in the ISB and 12.6-times higher in the ESB of sprouting tubers. Moreover it was noteworthy, that these two sprout regions also exhibited many-times higher PPO (Table 3B) and POD activities (Table 3C) than the tuber tissue. The differences in TSP, PPO and POD between these three tissue types were all statistically significant $(\mathrm{P}<0.05)$, on average and within the GTs. Obviously, this strong boost in all three components observed in the ISB and ESB was generated in order to protect the sprouts against pathogen invasions and/or other environmental impacts. This notion is supported by the fact that all GTs exhibited by far the highest levels of TSP, PPO and POD within the ESB, i.e. a sprout region located outside the tubers, where the risk for wounding and infections is very high. As mentioned already, plant phenols have strong protective functions, similarly, as the enzymes studied in this work. Thus, the PPO is relevant in the initial stage of defense and catalyses the oxidation of plant phenols released by membrane damage from the cells, whereby the reaction products inhibit patho-enzymes as well as pathogens (Tomiyama et al., 1967; Weber et al., 1996). Peroxidases, again, are involved in the bio-synthesis of suberin, lignin and/or lignin related polymers as well as in the cross linking of cell wall polysaccharides and proteins (Borchert, 1978; Espelie et al., 1986; Lagrimini, 1991; Silva et al., 2008). In this respect, the following findings were interesting.

After one week of incubation with Pba injected at a density of $5 \times 10^{8} \mathrm{cfu} \mathrm{ml}^{-1}(2 \times 50 \mu \mathrm{l}$; a-test $)$ underneath the sprouts of each test-tuber, no soft rot disease could be initiated (Figure 3). Obviously, the bacteria were defended successfully as indicated by white layers of corky cells surrounding the infection focus in the tubers of all GTs. This was a bit surprising, because only $10 \mu \mathrm{l}$ of the same Pba concentration are sufficient to cause rotting on the wound surface of normal, non-sprouting tubers (Figure 2a). The inhibition of a many-times higher Pba density $(100 \mu 1)$ may reflect the high impact of the defense potential generated in the ISB of sprouting tubers, where the bacteria were injected initially. Probably, this strong defense response was based on the high levels of TSP (Table 3A), PPO (Table 3B) and POD (Table 3C) present in the ISB. In this manner, the ISB might function as a barrier that blocks the pathogens on their route from contaminated tubers into the ESB, where they cause blg symptoms.

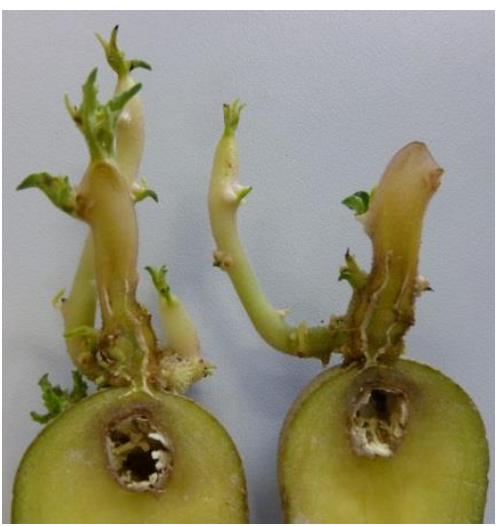

(B 165)

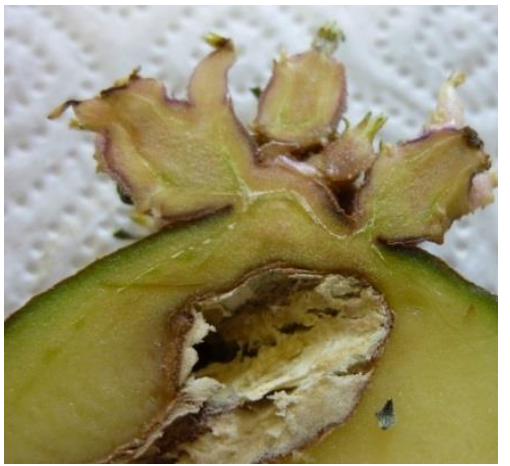

(P 92388)

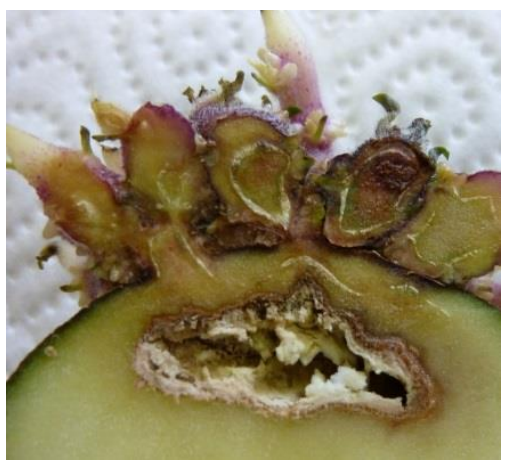

(L 696)

Figure 3. Necrosis formation in tubers of the different genotypes inoculated with Pba (a-test) and uncubated for one week at $20^{\circ} \mathrm{C}$

In order to overcome this barrier, in another set of trials a higher density of Pba bacteria $\left(10^{9} \mathrm{cfu} \mathrm{ml}^{-1} ; \mathrm{b}\right.$-test $)$ was used for infection. After one week of incubation, all tubers and sprouts of the two clones L 696 and P 92388 were rotted, and also B 165-tubers showed soft rot symptoms (Figure 4a). However, the sprouts of this clone were less or not at all affected by pathogens. Most sprouts looked healthy and could be transferred into the soil (Figure 4b) for plant growth in the greenhouse (Figure 4c) and production of tubers (Figure 4d) that remained healthy during the storage period. Obviously, the bacteria were blocked on their route from rotted tubers into the sprouts and it was interesting thus to find the reasons for this effect. In fact, the t-clone B 165 had high levels of TSP, PPO and POD in its ISB, a tendency, however, that was not too different from those of the other GTs (Table 3A, 3B, 3C). But another aspect could be of interest in this frame. Thus, B 165 had the highest levels of PPO and POD in its ESB among the GTs (Table 3B, 3C) and above all, its ESB-PPO levels were pronounced. As already mentioned, the PPO plays an essential role in the initial stage of plant defense (Weber et al., 1996), and products of phenol 
oxidation inhibit patho-enzymes and pathogens. Accordingly, these high levels in ESB-PPO (Table 3B) could be decisive for a defense of pathogens in B 165-sprouts. In a later phase, also the peroxidases may have contributed with their involvement in the bio-synthesis of suberin and lignin, i.e. corky and woody substances that cannot be degraded by patho-enzymes (Borchert, 1978; Espelie et al., 1986; Lagrimini, 1991; Silva et al., 2008). Indeed, the sprouts of the t-clone B 165 were a bit hard and woody, whereas those of the other GTs were thick and fleshy. Individual fibers became visible, when sprouting B 165-tubers were halved. This could be well observed after 24 hours (Figure 5a) and became more clear $48 \mathrm{~h}$ after wounding these tubers (Figure 5b). Histochemical analysis (phloroglucinol-HCl staining) revealed embedding of lignin polymers in the tissue of sprout sections cut from B 165-tubers (Figure 5c), a property that was less evident within appropriate L 696-derived samples (Figure 5d). In this case, the route looked free, so that the pathogens could move unhindered from contaminated tubers into the sprouts. All these findings suggest that embedding of lignin in the sprout basis is a main factor for blg tolerance.

\subsection{Some Other Factors}

The s-clone L 696 had on average a significantly lower number of sprouts $(\mathrm{P}<0.05)$ than the other GTs (Table 4). But, this seems to have no tremendous effect on blg tolerance, whereas another aspect could be of interest. Thus, the t-clone B 165 showed on average a significantly lower wound-diameter $(\mathrm{P}<0.05)$ measured after the sprouts were removed from its tubers, than the other two GTs that had values $>3.0 \mathrm{~mm}$ in diameter (Table 4). Doubtless, the joints between tubers and sprouts were better sealed by lignin within clone B 165 (Figure 5b), a property that could be helpful to reduce the infection risk often associated with mechanical damage to tubers. In addition, it may be difficult for pathogens to get through this lignin barrier from tubers into the sprouts in order to cause blg. Hence, the t-clone B 165 combined a range of properties that provided high protection against blg in practice.

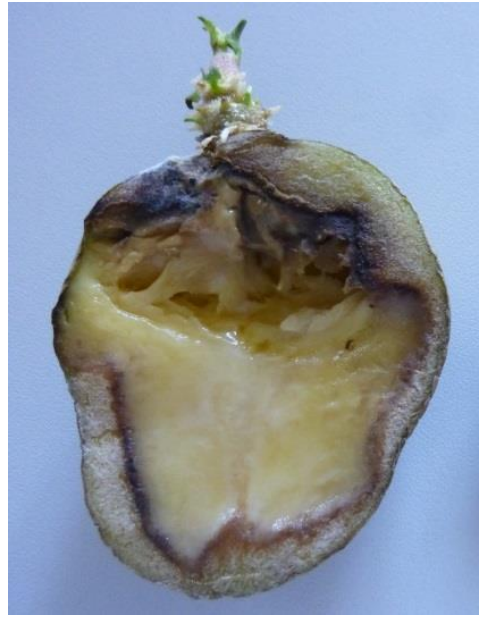

(a)

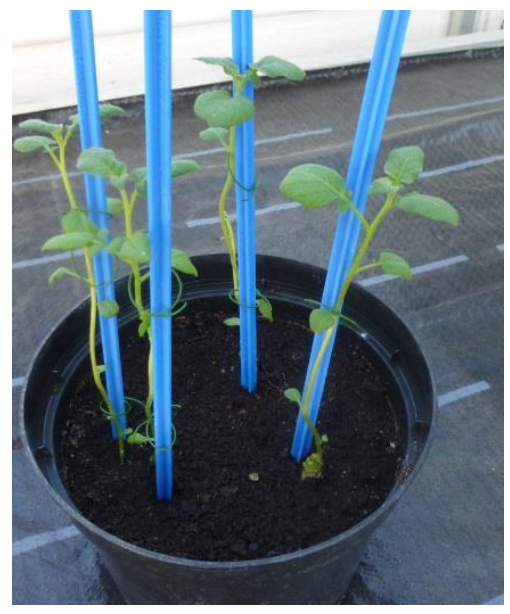

(c)

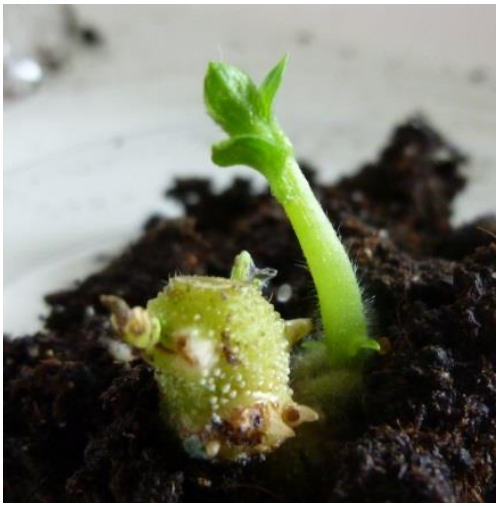

(b)

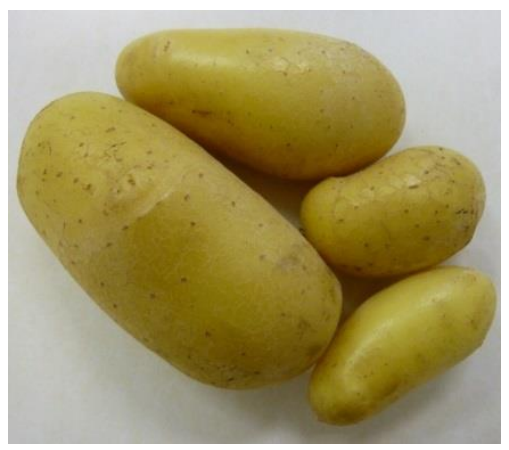

(d)

Figure 4. Tuber of the t-clon B 165 incubated with Pba bacteria under b-test conditions for one week at $20{ }^{\circ} \mathrm{C}$ (a). After incubation, the sprouts were excised from rotted tubers, transferred into the soil (b) for plant growth in the glasshouse (c) and production of progeny tubers (d). 


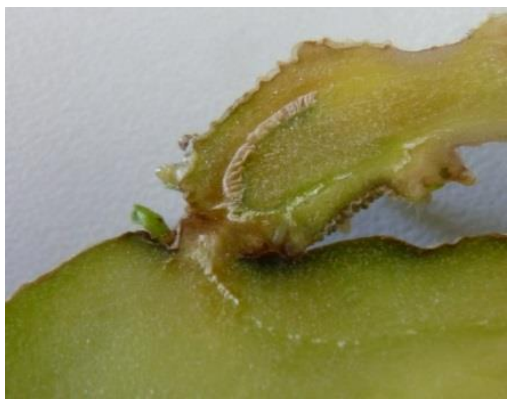

(a)

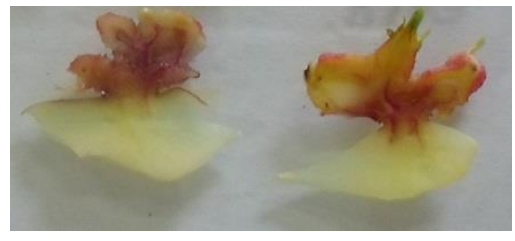

(c)

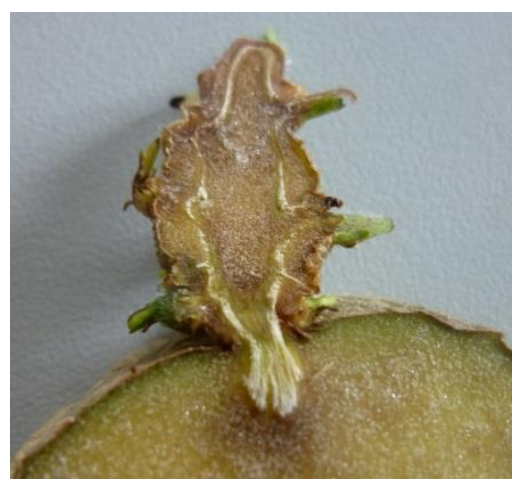

(b)

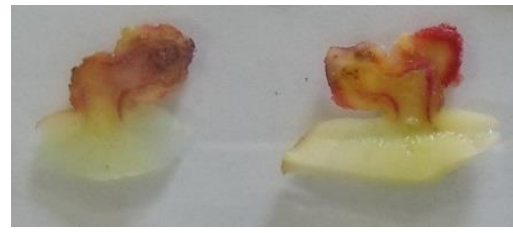

(d)

Figure 5. Fibers in B 165-sprouts observed $24 \mathrm{~h}$ (a) and $48 \mathrm{~h}$ (b) after wounding the test-tubers, and sprout tissue sections derived from the clones B 165 (c) and L 696 (d) that were stained for lignin with phloriglucinol-HCl

\subsection{Conclusions}

The results have clearly shown that a high portion of oversized tubers, strong lenticell swellings, a weak defense potential in tuber tissue coinciding with low antioxidant capacities and reduced necrosis formation are major risk factors for potato blg. In this frame, however, the big tubers and strong lenticell swellings are most relevant. On the other hand, embedding of lignin in the sprout basis can be seen as key factor for blg tolerance. Together with PPO, POD and phenols, this lignin forms a barrier that blocks the pathogen route between contaminated tubers and sprouts and prevents thus initiation of blg disease.

\section{Acknowledgements}

Dr. R. Hofferbert from the EROPLANT Plant Breeding Company, Lueneburg, Germany is thanked for supplying the three potato clones studied in this frame. Furthermore, we would like to thank Ilona Schollenberg (JKI) for excellent technical assistance during this work.

\section{References}

Barras, F., van Gijsegem, F., \& Chatterjee, A. K. (1994). Extracellular enzymes and pathogenesis of soft rot Erwinia. Annual Review of Phytopathology, 32, 201-234. https://doi.org/10.1146/annurev.py.32.090194.0012 21

Bartling, S., Wegener, C., \& Olsen, O. (1995). Synergism between pectate lyase isoenzymes that depolymerize both pectate and pectine. Microbiology, 141, 873-881. https://doi.org/10.1099/13500872-141-4-873

Bi, J. L., Felton, G. W., Murphy, J. B., Howles, P. A., Dixon, R. A., \& Lamb, C. J. (1997). Do plant phenolics confer resistance to specialist and generalist insect herbivores? Journal Agricultural and Food Chemistry, 45, 4500-4504. https://doi.org/10.1021/jf970555m

Borchert, R. (1978). Time course and spatial distribution of phenylalanine ammonia-lyase and peroxidase activity in wounded potato tuber tissue. Plant Physiology, 62, 789-793. https://doi.org/10.1104/pp.62.5.789

Cahill, D. M., \& McComb, J. A. (1992). A comparison of changes in phenylalanine ammonia-lyase activity, lignin and phenolic synthesis in the roots of Eucalyptus calophylla (field resistant) and E. marginata (susceptible) when infected with Phytophthora cinnamomi. Physiological and Molecular Plant Pathology, 40, 315-332. https://doi.org/10.1016/0885-5765(92)90014-M

Collmer, A., \& Keen, N. T. (1986). The role of pectic enzymes in plant pathogenesis. Annual Review of Phytopathology, 24, 383-409. http://doi.org/10.1146/annurev.py.24.090186.002123 
Czajkowski, R., de Boer, W. J., \& van der Wolf, J. M. (2013) Chemical disinfectants can reduce potato blackleg caused by Dickeya solani. European Journal of Plant Pathology, 136(2), 419-432. https://doi.org/10.1007/s10658- 013-0177-8.

Czajkowski, R., Pérombelon, M. C. M, van Veen, J. A., \& van der Wolf J. M. (2011). Control of blackleg and tuber soft rot of potato caused by Pectobacterium and Dickeya species: a review. Plant Pathology, 60, 999-1013. https://doi.org/10.1111/j.1365-3059.2011.02470.x

Czajkowski, R., Pérombelon, M. C. M, Jafra, S., Lojkowska, E., Potrykus, M., van der Wolf, J. M., \& Sledz, W. (2015). Detection, identification and differentiation of Pectobacterium and Dickeya species causing potato blackleg and tuber soft rot: a review. Annals of Applied Biology, 166(1), 18-38. https://doi.org/10.1111/aab.12166.

DAERA (2019). Blackleg of potato. Information Sheet. DAERA, Northern Ireland, p. 1-4. Retrieved from https://www.daera-ni.gov.uk/articles/blackleg-potato-dickeya-solani

De Boer, S. H., \& Rubio, I. (2016). Blackleg of Potato. The Plant Health Instructor 2004, updated 2016. https://doi.org/10.1094/PHI-I-2004-0712-01

De Haan, E. G., Dekker-Nooren, T. C. E. M., van den Bovenkamp, G. W., Speksnijder, A. G. C. L., van der Zouwen, P. S., \& van der Wolf, J. M. (2008). Pectobacterium carotovorum subsp. carotovorum can cause potato blackleg in temperate climate. European Journal Plant Pathology, 122, 561-569. https://doi.org/10.1007/ s10658-008-9325-y

Espelie, K. E., Franceschi, R. V., \& Kollattukudy, P. E. (1986). Immunocytochemical localization and time course of appearance of an anionic peroxidase associated with suberization in wound-healing potato tuber tissue. Plant Physiology, 81(2), 487-492. https://doi.org/101104/pp.81.2.487.

Fox, R. T. V., Manners, G. J., \& Myers, A. (1971). Ultrastructure of entry and spread of Erwinia carotovora var. atroseptica into potato tubers. Potato Research, 14, 61-73. https://doi.org/10.1007/BF02355930

Fox, R. T. V., Manners, G. J., \& Myers, A. (1972). Ultrastructure of tissue disingration and host reactions in potato tubers infected by Erwinia carotovora var. atroseptica. Potato Research, 15, 130-145. https://doi.org/10.1007/BF02355960

Fredricks, A. L., \& Metcalf, H. N. (1970). Potato Blackleg Disease. American Potato Journal, 47(9), 337-343. https://doi.org/10.1007/BF02861278

Ghanekar, A. S., Padwal-Desai, S. R., \& Nadkarni, G. B. (1984). The involvement of phenolics and phytoalexins in resistance of potato to soft rot. Potato Research, 27(2), 189-199. https://doi.org/10.1007/BF02357464

Jockusch, H. (1966). The role of host genes, temperature and polyphenol oxidase in the necrotization of TMV infected tobacco tissue. Journal of Phytopathology, 55(2), 185-192. https://doi.org/10.1111/j.1439-0434.1966.tb022 22.x

Kumar, A., Pundhir, V. S., \& Gupta K. C. (1991). The role of phenols in potato tuber resistance against soft rot caused by Erwinia carotovora ssp. carotovora. Potato Research, 34, 9-16. https://doi.org/10.1007/BF02358090

Lagrimini, L. M. (1991). Wound-induced deposition of polyphenols in transgenic plants overexpressing peroxidase. Plant Physiology, 96, 577-583. https://doi.org/10.1104/pp.96.2.577

Nicholson, R. L., \& Hammerschmidt, R. (1992). Phenolic compounds and their role in disease resistance. Annual Review of Phytopathology, 30, 369-389. https://doi.org/10.1146/annurev.py.30.090192.002101

Perombelon, M. C. M. (1974). The role of seed tuber in the contamination by Erwinia carotovora of potato crops in Scotland. Potato Research, 17, 187-199. https://doi.org/10.1007/BF02360386

Perombelon, M. C. M., \& Lowe, R. (1975). Studies on the initiation of bacterial soft rot in potato tubers. Potato Research, 18(1), 64-82. https://doi.org/10.1007/BF02361776

Perombelon, M. C. M. (1992). Potato blackleg: Epidemiology, host-pathogen interaction and control. Netherland Journal of Plant Pathology, 98(2), 135-146. https://doi.org/10.1007/BF01974480

Perombelon, M. C. M. (2002). Potato diseases caused by soft rot erwinias: An overview of pathogenesis. Plant Pathology, 51(2), 1-12. https://doi.org/10.1046/j.0032-0862.2001.Shorttitle.doc.x

Poberezny, J., Goscinna, K., Wszelaczynska, E., \& Szeczepanek M. (2017). Influence of mechanical damage and storage on various quality aspects of potatoes. Journal of Applied Botany and Food Quality, 90, 259-265. 
https://doi.org/10.5073/JABFQ.2017.090.032

Popov, I. N., \& Lewin, G. (1996). Photochemiluminescent detection of antiradical activity: IV testing of lipid-soluble antioxidants. Journal of Biochemical and Biophysical Methods, 31, 1-8. https://doi.org/10.1016/0165-022x(95)00021-i

Reyes, L. F., \& Cisneros-Zevallos, L. (2003). Wounding stress increases the phenolic content and antioxidant capacity of purple-flesh potatoes (Solanum tuberosum L.). Agricultural and Food Chemistry, 51(18), 5296-5300. https://doi.org/10.1021/jf034213u

Reyes, L. F., Villarreal J. E., \& Cisneros-Zevallos, L. (2007). The increase in antioxidant capacity after wounding depends on the type of fruit or vegetable tissue. Food Chemistry, 101(3), 1254-1262. https://doi.org/10.1016/ j.foodchem.2006.03.032

Rittinger, P. A., Biggs, A. R., \& Peirson, D. R. (1987). Histochemistry of lignin and suberin deposition in boundary layers formed after wounding in various plant species and organs. Canadian Journal of Botany, 65(9), 1886-1892. https://doi.org/10.1139/b87-258

Silva, M. C., Guerra-Guimaraes, L., Loureiro, A., \& Nicole, M. R. (2008). Involvement of peroxidases in the coffee resistance to orange rust (Hemileia vastatrix). Physiological and Molecular Plant Pathology, 72, 29-38. https://doi.org/10.1016/j.pmpp.2008.04.004

Tomiyama, K., Sakai, R., Otani, Y., \& Takemori T. (1967). Phenol metabolism in relation to disease resistance of potato tubers. Plant and Cell Physiology, 8, 1-13. https://doi.org/10.1093/oxfordjournals.pcp.a079245

Toth, I. K., Bells, S. B., Holeva, M. C., \& Birch, P. R. J. (2003). Soft rot Erwiniae: From genes to genomes. Molecular Plant Pathology, 4(1), 17-30. https://doi.org/10.1046/j.1364-3703.2003.00149.x

Toth, I. K., \& Birch, P. R. J. (2005). Rotting softly and stealthily. Current Opinion in Plant Biology, 8, 424-429. https://doi.org/10.1016/j.pbi.2005.04.001

Toth, I. K., van der Wolf, J. M., Saddler, G. S., Lojkowska, E., Helias, V., Pirhonen, M., Tsror L., \& Elphinstone, J. G. (2011). Dickeya species: an emerging problem for potato production in Europe. Plant Pathology, 60(3), 385-399. https://doi.org/10.1111/j.1365-3059.2011.02427.x

Tsror, L., Erlich, O., Lebiush, S., Hazanovsky, M, Zig, U., Slawiak, M., Grabe, G., van der Wolf, J. M., \& van de Haar, J. J. (2009). Assessment of recent outbreaks of Dickeya sp. (syn. Erwinia chrysanthemi) slow wilt in potato crops in Israel. European Journal of Plant Pathology, 123, 311-320. https://doi.org/10.1007/s10658-008-9368-0

Vance, C. P., Kirk, T. K., \& Sherwood, R. T. (1980). Lignification as a mechanism of disease resistance. Annual Review of Phytopathology, 18, 259-288. https://doi.org/10.1146/annurev.py.18.090180.001355

Weber, J., Olsen, O., Wegener, C., \& von Wettstein, D. (1996). Digalacturonates from pectin degradation induce tissue responses against potato soft rot. Physiological and Molecular Plant Pathology, 48(6), 389-401. https://doi.org/10.1006/pmpp.1996.0031

Wegener, C. B. (2002). Induction of defence responses against Erwinia soft rot by an endogenous pectate lyase in potatoes. Physiological and Molecular Plant Pathology, 60, 91-100. https://doi.org/10.1006/pmpp.2002.0377

Wegener, C. B. (2013). Blackleg of Potato: Risk factors and the potential of breeding. Kartoffelbau, Potato Production, Specialist Journal, 8, 28-31.

Wegener, C. B., \& Jansen, G. (2010). Antioxidant capacity in cultivated and wild Solanum species: The effect of wound stress. Food and Function, 1(2), 209-218. https://doi.org/10.1039/c0fo00063a.Epub20100ct.5

Wegener, C. B., \& Jansen, G. (2013). Antioxidants in different potato genotypes: Effect of drought and wounding stress. Agriculture, 3(1), 131-146. https://doi.org/10.3390/agriculture3010131

\section{Copyrights}

Copyright for this article is retained by the author(s), with first publication rights granted to the journal.

This is an open-access article distributed under the terms and conditions of the Creative Commons Attribution license (http://creativecommons.org/licenses/by/3.0/). 